\title{
Selected Literature Watch
}

\section{Firearm Violence}

Castillo-Carniglia A, Kagawa RMC, Webster DW, et al. (2017). Comprehensive background check policy and firearm background checks in three U.S. states. Inj Prev. [Epub ahead of print]; doi:10.1136/injuryprev-2017-042475.

Cipriani G, Danti S, Carlesi C, Di Fiorino M. (2017). Armed and aging: Dementia and firearms do not mix! J Gerontol Soc Work. [Epub ahead of print]; doi:10.1080/01634372.2017.1376240.

Díez C, Kurland RP, Rothman EF, et al. (2017). State intimate partner violence-related firearm laws and intimate partner homicide rates in the United States, 1991 to 2015. Ann Intern Med. 167, 536-543.

Dillon KP, Bushman BJ. (2017). Effects of exposure to gun violence in movies on children's interest in real guns. JAMA Pediatr. [Epub ahead of print]; doi:10.1001/jamapediatrics.2017.2229.

Meszaros J. (2017). Falling through the cracks: The decline of mental health care and firearm violence. J Ment Health. 26, 359-365.

Peek-Asa C, Butcher B, Cavanaugh JE. (2017). Cost of hospitalization for firearm injuries by firearm type, intent, and payer in the United States. Inj Epidemiol. 4, 20.

Resnick S, Smith RN, Beard JH, Holena D, et al. (2017). Firearm deaths in America: Can we learn from 462,000 lives lost? Ann Surg. 266, 432440.

Rosenberg M, Ranapurwala SI, Townes A, Bengtson AM. (2017). Do black lives matter in public health research and training? PLoS One. 12, e0185957.

Simckes MS, Simonetti JA, Moreno MA, et al. (2017). Access to a loaded gun without adult permission and school-based bullying. J Adolesc Health. 61, 329-334.

Smith RN, Seamon MJ, Kumar V, et al. (2017). Lasting impression of violence: Retained bullets and depressive symptoms. Injury. [Epub ahead of print]; doi:10.1016/j.injury.2017.08.057.

Stroebe W, Leander NP, Kruglanski AW. (2017). The impact of the Orlando mass shooting on fear of victimization and gun-purchasing intentions: Not what one might expect. PLoS One. 12, e0182408.

\section{Hatred and Violence}

Benier K. (2017). The neighborhood context of hate crime: A comparison of violent and property offenses using rare events modeling. Violence Vict. 32, 584-608.

Cichocka A, Dhont K, Makwana AP. (2017). On self-love and outgroup hate: Opposite effects of narcissism on prejudice via social dominance orientation and right-wing authoritarianism. Eur J Pers. 31, 366-384.

Danielson CM, Emmers-Sommer TM. (2017). "She stopped me from killing myself”: Bullied bloggers' coping behaviors and support sources. Health Commun. 32, 977-986.

Gil-Borrelli CC, Martín-Ríos MD, Rodríguez-Arenas MÁ; en representación del Grupo de Investigación SIVIVO. (2017). Proposed action for the detection and care of victims of hate violence for health professionals. Med Clin (Barc). [Epub ahead of print]; doi:10.1016/j.medcli .2017.06.017.

Valcore JL. (2017). Sexual orientation in state hate crime laws: Exploring social construction and criminal law. J Homosex. 1-24; doi: 10.1080/ 00918369.2017.1380992.

White MH, Crandall CS. (2017). Freedom of racist speech: Ego and expressive threats. J Pers Soc Psychol. 113, 413-429.

Wilkinson WW, Peters CS. (2017). Evaluations of antigay hate crimes and hate crime legislation: Independent and differentially predicted. J Homosex. 1-17; doi: 10.1080/00918369.2017.1364556. 